\title{
Imidazole and beta-carotene photoprotection against photodynamic therapy evaluated by synchrotron infrared microscopy
}

\author{
Gabriela N. Bosio ${ }^{\text {a,* }}$, Julieta Parisi ${ }^{\text {b }}$, Fernando S. García Einschlag a,*, Daniel O. Mártire a \\ a Instituto de Investigaciones Teóricas y Aplicadas, Universidad Nacional de La Plata, Calle 64 y Diagonal 113, CP1900, Argentina \\ b Instituto Multidisciplinario de Biologia Celular (IMBICE), CCT-La Plata-CONICET, Camino General Belgrano y 526, B1906APO, La Plata, Argentina
}

\section{A R T I C L E I N F O}

\section{Article history:}

Received 11 January 2017

Received in revised form 28 December 2017

Accepted 11 January 2018

Available online $\mathrm{xxxx}$

\section{Keywords:}

$\beta$-carotene

Imidazole

HeLa

HaCat

SKMEL-28

PDT

\begin{abstract}
A B S T R A C T
In order to better understand the role of $\beta$-carotene and imidazole on the Photodynamic Therapy (PDT) mechanism, synchrotron infrared microscopy was used to detect the associated intracellular biochemical modifications following the visible light irradiation of HeLa cells incubated with these compounds as typical hydrophobic and hydrophilic singlet oxygen quenchers, respectively. For this purpose, PDT was performed employing the hydrophilic sensitizer 5,10,15,20-Tetrakis (1-methyl-4-pyridinio) porphyrin tetra (p-toluenesulfonate), TMPyP, and the hydrophobic sensitizer 5-(4-Methoxycarboxyphenyl)-10,15,20-triphenyl-21H,23H-porphyrin. The single cell IR spectra of PDT-treated, PDT plus quencher-treated and control HeLa cells were recorded at the SOLEIL Synchrotron Infrared SMIS beamline targeting specifically the cell nucleus. Principal Component Analysis (PCA) was used to assess the IR spectral changes. PCA revealed that there is a frequency shift of the protein Amide I vibrational band for the assays with the TMPyP sensitizer, indicating changes in the protein secondary structures of the PDT-treated cancer cells compared to the controls. In addition, the scores in those cells treated with both quenchers appear to be similar to the controls indicating a photoprotective effect. Comparative experiments carried out with SKMEL-28 and HaCat cells showed non- significant photoprotective effects of $\beta$-carotene and imidazole.
\end{abstract}

(c) 2018 Elsevier B.V. All rights reserved.

\section{Introduction}

Singlet oxygen, $\mathrm{O}_{2}\left(\mathrm{a}^{1} \Delta_{\mathrm{g}}\right)$, is the lowest excited state of molecular oxygen [1-3]. Production of sufficient quantities of singlet oxygen in a biological environment can perturb cellular processes and ultimately cause cell death via apoptosis or necrosis [4,5]. The cytotoxic effect of singlet oxygen is currently used in clinical practice in a treatment modality called photodynamic therapy (PDT), whereby the controlled production of singlet oxygen leads to the eradication of undesired tissue [6].

It was recently demonstrated using hydrophilic and hydrophobic sensitizers and HeLa cells, a cell type derived from human cervical cancer, that intracellular $\beta$-carotene does not quench $\mathrm{O}_{2}\left(\mathrm{a}^{1} \Delta_{\mathrm{g}}\right)$ as revealed by time-resolved $\mathrm{O}_{2}\left(\mathrm{a}^{1} \Delta_{\mathrm{g}}\right)$ phosphorescence experiments [7]. On the other hand, in the same paper the photoprotective effect of $\beta$-carotene was manifested in experiments also performed with the same sensitizers and cell lines. The photoprotective effect of the carotenoid was shown by different types of experiments, such as bright field microscope images for morphology changes (e.g., membrane located vacuole formation and chromatin condensation), the 3-(4,5-dimethylthiazol-2-

\footnotetext{
* Corresponding authors.

E-mail addresses: gbosio@inifta.unlp.edu.ar (G.N. Bosio), fgeins@inifta.unlp.edu.ar (F.S. García Einschlag).
}

yl)-2,5-diphenyltetrazolium bromide (MTT) assay for enzymatic activity, the Trypan Blue assay for membrane permeability, among others [7]. From these results it was inferred that the principal mechanism of $\beta$-carotene photoprotection involves trapping of radicals that are also produced as a consequence of sensitizer irradiation with visible light and the subsequent reactions of $\mathrm{O}_{2}\left(\mathrm{a}^{1} \Delta_{\mathrm{g}}\right)$.

Imidazole is a well-known $\mathrm{O}_{2}\left(\mathrm{a}^{1} \Delta_{\mathrm{g}}\right)$ quencher [30], which was shown to inhibit the UV-A induced pattern of mitogen-activated protein kinase in human skin fibroblasts (MAPK) activation, a process mediated by $\mathrm{O}_{2}\left(\mathrm{a}^{1} \Delta_{\mathrm{g}}\right)$, [8]: Imidazole derivatives also were demonstrated to inhibit MPAK in B16-F0 and HeLa cells [9].

On the basis of this background we were motivated to investigate whether: 1$)$ even though $\beta$-carotene is unable to quench $\mathrm{O}_{2}\left(\mathrm{a}^{1} \Delta_{\mathrm{g}}\right)$ in mammalian cells, its radical trapping effect has any consequence on the nuclear protein changes associated with early stages of apoptosis, 2 ) imidazole presents a photoprotective effect on cells exposed to PDT.

To this end, we employed here the Fourier transform infrared (FTIR) microspectroscopy, a vibrational spectroscopy technique, which is used as a diagnostic tool useful for probing molecular changes within cells or tissues submitted to different treatments. This technique was previously used to follow the intracellular changes of biological composition of cells such as proteins and DNA [10]. In particular, Srichan et al. employed synchrotron light to study the PDT on HeLa cells with the 
sensitizer hypocrillile [7]. For our experiments two different sensitizers were employed. One of them was the hydrophilic cationic porphyrin sensitizer 5,10,15,20-Tetrakis(1-methyl-4-pyridinio) porphyrin tetra (p-toluenesulfonate), TMPyP, which tends to accumulate in the cell nucleus, contrarily to what was observed with hypericine or hypocrelinne, but an appreciable amount can still be found in the cytoplasm $[9,11]$. The second photosensitizer employed here was 5-(4Methoxycarboxyphenyl)-10,15,20-triphenyl-21H,23H-porphyrin, (TPPCOOMe). Because of its hydrophobic nature, this latter molecule localizes in a different domain of a living cell than does TMPyP.

The main goal of the present work is to probe molecular changes observed inside HeLa cells (i.e., proteins global changes) using the internal source of the continuum XL infrared microscope as a result of the localization of the sensitizers (TMPyP or TPPCOOMe) and $\beta$-carotene or imidazole as typical hydrophobic and hydrophilic potential photoprotective agents, respectively. For this purpose, experiments were performed with and without visible light irradiation at two different quenchers concentration. In particular, data were analyzed in the region of the Amide I band $\left(1600-1700 \mathrm{~cm}^{-1}\right)$. Amide I and Amide II $\left(1500-1560 \mathrm{~cm}^{-1}\right)$ bands arise primarily from the $\mathrm{C}=\mathrm{O}$ and $\mathrm{C}-\mathrm{N}$ stretching vibrations of the peptide backbone, respectively. FTIR has been shown to be particularly sensitive to protein secondary structure based on the vibrational frequency of the Amide I $(C=0)$ band, which is affected by different hydrogen bonding environments for $\alpha$-helix, $\beta$-sheet, and unordered structures. For most proteins, a mixture of secondary structures exists, and in this case, the Amide I band represents a combination of these components $[11,12,10]$. For comparison similar experiments were carried out with SKMEL-28 (human melanoma cells) and HaCat (human normal skin keratinocytes cells). HeLa and HaCat cell types are of epithelial origin and are considered to be an excellent comparative model between tumoral vs. non-tumoral studies in vitro [13]. SKMEL-28 cells derive from a metastatic melanoma, which is the most hardly treated skin cancer. Melanoma cells are resistant to traditional chemotherapy and radiation therapy, and thus photodynamic therapy can provide a promising treatment [14].

\section{Materials and Methods}

\subsection{Chemicals}

All trans- $\beta$-carotene ( $>97 \%$, Sigma-Aldrich), TMPyP, (Sigma-Aldrich), 3-(4,5-dimethylthiazol-2-yl)-2,5 diphenyltetrazolium bromide, MTT, (Sigma-Aldrich), and Imidazole (Sigma-Aldrich) were used as received. TTPCOOMe, was synthesized according to a published procedure [7].

\subsection{PDT Experiments}

Photodynamic therapy has been induced in cancer HeLa, SKMEL-28, and HaCat cell lines. The IR study aimed at identifying the change induced by various treatments, with or without visible light irradiation. According to previously published work from Dr. Dumas group [12], we concentrated on the biochemical changes that might have been induced in the nucleus of the cells.

\subsection{Cell Culture}

HeLa cells from the American Type Culture Collection (ATCC CCL-2) were cultured on low-e microscope slides in D-MEM containing 10\% fetal bovine serum. SKMEL-28 cells from the American Type Culture Collection (ATCC HTB-72) were cultured on low-e microscope slides in MEM containing $10 \%$ fetal bovine serum. HaCaT cells, provided by IMBICE (Multidisciplinary Institute of Cellular Biology, Argentina), were cultured on low-e microscope slides in RPMI 1640 M (Micro-Vet SRL, C.A.B.A, Argentina). Then, the cells were incubated with $10 \mu \mathrm{M}$ TMPyP or TPPMeCOO $24 \mathrm{~h}$ with or without the quenchers. After incubation cells were irradiated for $1 \mathrm{~h}$ with a $5 \mathrm{~W}$ fluorescent lamp (see spectral irradiance in the Supplementary Material, Fig. SM1) with a photon rate of $2.179 \times 10^{-7}$ eins/Ls, as determined by ferrioxalate actinometry for $\lambda \leq 500 \mathrm{~nm}$ [15]. From Fig. SM1 the photon rate in the whole wavelength emission range was calculated to be $2,179 \times 10^{-8}$ eins/Ls. Then, cells were immediately fixed with $10 \%$ formalin in phosphate buffer saline (PBS) for $20 \mathrm{~min}$ at room temperature for conserving the cells [16]. The cells were washed first with PBS and then with water and dried.

\subsection{MTT Assay}

Cytotocixity in mammalian cells was estimated using metabolic competence by the colorimetric method of Mosma [17-19] as modified by Twentyman and Luscombe [20]. This assay measures the reduction of tetrazolium salt (3-(4,5-dethylthiazol-2-yl) 2,5 diphenyl tetrazolium bromide) to formazan by dehydrogenase enzymes of intact mitochondria in living cells.

For this analysis $1.5 \times 10^{3}$ cells/well were cultured in 96 multi-well plate and grown at $37^{\circ} \mathrm{C}$ in $5 \% \mathrm{CO}_{2}$ humid atmosphere in complete culture medium for $24 \mathrm{~h}$. This medium was then replaced with different extracts containing TMPyP or TPPCOOMe both in the presence and absence of $\beta$-carotene or imidazole. The samples were irradiated with visible light and then washed with PBS and fresh medium containing MTT reagent ( $1 \mathrm{mg} / \mathrm{mL}$ final concentration) (Sigma, St. Louis, MO, USA) was added. After $3 \mathrm{~h}$ incubation, cells were washed again with PBS. Color was developed by the addition of $100 \mu \mathrm{L}$ dimethylsulfoxide (DMSO) (Merck, Química Argentina SAIC, Argentina) to each well for cells lysis and formazan crystals dissolution. The plates were shaken for $10 \mathrm{~min}$ and the absorbance was measured at $540 \mathrm{~nm}$ using an automatic ELISA Plate Solver reader (7530 Microplate Reader Cambridge Technology, Inc., St. Watertown, MA, USA). Ethanol (5\%) was used as positive control. Each experiment was independently repeated three times.

Phototoxicity control experiments with HeLa, SKMEL-28, and HaCat cells were carried out with cells incubated in the presence of different amounts of $\beta$-carotene or imidazole solutions without the sensitizers. Results are shown in the Supplementary Material (Fig. SM2). No phototoxicity of the quenchers was observed in the concentration range employed in the PDT experiments.

\subsection{FTIR Microspectroscopy}

The synchrotron based Fourier transform infrared (SR-FTIR) microspectroscopy was used to particularly observe the changes of the chemical structure of the biological molecules in the nucleus of mammalian cells. The IR spectra of the untreated cells and sensitizers/ quenchers treated cells were measured and compared. The IR spectral changes between the untreated cells and sensitizers/quenchers treated cells were analyzed by multivariate statistical analysis.

The experiments were performed at the infrared SMIS beamline, SOLEIL Synchrotron, L'Orme des Merisiers, Gif sur Yvette, France. The IR spectra collected in reflection mode from individual cells grown directly on low-e slides were recorded using a Continuum XL microscope coupled to a ThermoNicolet 5700 spectrometer $\left(8 \mathrm{~cm}^{-1}\right.$ spectral resolution, 256 scans per spectrum, aperture dimension $8 \times 8 \mu^{2}$, magnification $32 \times$ NA 0.65 Schwarzschild objective, in reflection and confocale modes). The reference spectrum was recorded with the same parameters and conditions, but outside the cells.

\subsection{Data Analysis}

Cell spectra recorded one by one, with 50 to 100 individual cells per sample were analyzed. Principal Component Analysis (PCA) was used for outliers detection within samples and also for comparison between samples (see below). Several preprocessing techniques were tested including: Savitzky-Golay baseline correction [21], non-resonant Mie 
Scattering baseline correction [22], numerical evaluation of first/second order derivative spectra by the Savitzky-Golay method [21,23], multiplicative scattering correction [23], Standard Normal Variate (SNV) [21,23], Euclidean normalization [23] and min-max normalization [21]. It is worth mentioning that the conclusions obtained by PCA were independent of the preprocessing technique used. Corrections due to standing wave effect [24] were not performed because we focused on band shifts that should not be affected by these effects.

\subsection{Samples Analyzed during the Allocated Beamtime}

Table 1 shows the various samples studied by IR microspectroscopy.

\section{Results and Discussion}

\subsection{Spectra Analysis}

Fig. 1 shows the 256 scans accumulated IR spectra of individual control HeLa cells without any mathematical treatment i.e., sample S01. As can be seen in Fig. 1, there is a huge dispersion between the spectra from the same sample. In part, this could be due to Mie scattering. The Mie scattering is frequently present in round-shaped samples comparable in size to the irradiation wavelengths used in infrared microspectroscopy. Cell nuclei typically scatter light in the 5-10 $\mu \mathrm{m}$ wavelength range, affecting the Amide I band. Mie scattering can be detected in IR spectra by a sinusoidal shape of the baseline, a splitting of the $\mathrm{C}=0$ band at $1740 \mathrm{~cm}^{-1}$, and a shift of the Amide I band from 1652 to $1656 \mathrm{~cm}^{-1}$ to $1640-1650 \mathrm{~cm}^{-1}$ [25], as can be seen in Fig. 1 for HeLa cells and/or in Fig. SM3 for SKMEL-28 and HaCat (see Supplementary Material). Thus, in order to minimize scattering effects on the spectra, a Savitzky-Golay baseline correction was applied to each sample. Three user-defined baseline regions were selected (i.e., 4000-3595, $2775-1750$ and $950-800 \mathrm{~cm}^{-1}$ ) in order to calculate a smooth baseline for each sample through the entire wave number range (4000-800 $\mathrm{cm}^{-}$ ${ }^{1}$ ). The baselines were calculated by means of a second order polynomial expansion around each point using a high number of baseline points ( $20 \%$ of the entire spectrum). For example, Fig. 2 shows the baselinecorrected spectra obtained for the control HeLa cells.

After baseline correction, only the 1710 to $1480 \mathrm{~cm}-1$ frequency region was considered in order to analyze in detail the Amide I absorption band. In addition, with the aim of detecting differences in the shapes of the amide bands rather than in their intensities, both offset correction and max normalization were applied.

Table 1

Samples studied by IR micro-spectroscopy.

\begin{tabular}{|c|c|}
\hline Sample & Description \\
\hline 1 & Control (untreated cells). \\
\hline 2 & $10 \mu \mathrm{M}$ TMPуP without irradiation. \\
\hline 3 & $10 \mu \mathrm{M}$ TPPCOOMe without irradiation. \\
\hline 7 & PDT therapy ( $1 \mathrm{~h}$ irradiation) with $10 \mu \mathrm{M}$ TMPyP plus $30 \mu \mathrm{M}$ imidazole. \\
\hline 8 & PDT therapy ( $1 \mathrm{~h}$ irradiation) with $10 \mu \mathrm{M}$ TMPyP plus $50 \mu \mathrm{M}$ imidazole. \\
\hline 10 & $\begin{array}{l}\text { PDT therapy ( } 1 \text { h irradiation) with } 10 \mu \mathrm{M} \text { TPPCOOMe plus } 30 \mu \mathrm{M} \\
\text { imidazole. }\end{array}$ \\
\hline 11 & $\begin{array}{l}\text { PDT therapy ( } 1 \text { h irradiation) with } 10 \mu \mathrm{M} \text { TPPCOOMe plus } 50 \mu \mathrm{M} \\
\text { imidazole. }\end{array}$ \\
\hline 12 & PDT therapy ( $1 \mathrm{~h}$ irradiation) with $10 \mu \mathrm{M}$ TMPyP plus $5 \mu \mathrm{M} \beta$-carotene. \\
\hline 13 & PDT therapy ( $1 \mathrm{~h}$ irradiation) with $10 \mu \mathrm{M}$ TMPyP plus $10 \mu \mathrm{M} \beta$-carotene. \\
\hline 15 & $\begin{array}{l}\text { PDT therapy ( } 1 \text { h irradiation) with } 10 \mu \mathrm{M} \text { TPPCOOMe plus } 5 \mu \mathrm{M} \\
\beta \text {-carotene. }\end{array}$ \\
\hline 16 & $\begin{array}{l}\text { PDT therapy ( } 1 \text { h irradiation) with } 10 \mu \mathrm{M} \text { TPPCOOMe plus } 10 \mu \mathrm{M} \\
\beta \text {-carotene. }\end{array}$ \\
\hline 17 & $\begin{array}{l}\text { PDT therapy ( } 1 \text { h irradiation) with } 10 \mu \mathrm{M} \text { TPPCOOMe plus } 15 \mu \mathrm{M} \\
\beta \text {-carotene. }\end{array}$ \\
\hline 18 & PDT therapy ( $1 \mathrm{~h}$ irradiation) with $10 \mu \mathrm{M}$ TMPyP. \\
\hline 19 & PDT therapy ( $1 \mathrm{~h}$ irradiation) with $10 \mu \mathrm{M}$ TPPCOOMe. \\
\hline
\end{tabular}

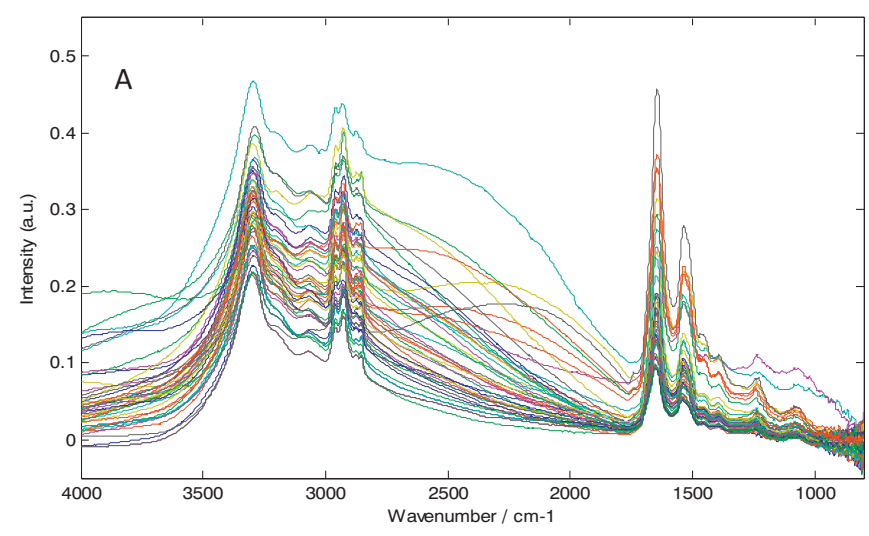

Fig. 1. Raw IR spectra obtained with control HeLa cells.

Finally, PCA analysis was performed on the sets of pre-treated spectra associated to each sample for identifying atypical spectra (outliers) within a given sample. For all samples, the two major principal components accounted for $>92.5 \%$ of the variance. Therefore, covariance error ellipses with 99\% confidence limits were drawn in the PC1-PC2 plane in order to detect and remove those spectra that strongly deviated from the distribution associated to each sample. After outliers removal, PCA/covariance ellipses were recalculated and the procedure was repeated until all remaining spectra were within the $99 \%$ confidence limits. See an example of the procedure in Fig. SM4 (Supplementary Material).

It is important to notice that many FTIR spectra were classified as outliers based on the data pre-treatment applied. This mathematical procedure enabled us to rule out spectra arising from cells in an advanced degree of apoptosis and or necrosis, which very much affect the shape of the cells resulting in a significant Mie scattering able to mask any change in the Amide I band.

\subsection{PDT Treatment on HeLa Cells}

We first analyzed the Amide I and Amide II bands $\left(1480-1720 \mathrm{~cm}^{-}\right.$ ${ }^{1}$ ) of the spectra. PCA scores and sample mean spectra in the region of for PDT-treated Hela cells, incubated with the sensitizer TMPyP (sample number 18) or TPPCOOMe (sample number 19) are displayed in Fig. 3.

Results obtained with the Min/Max, Euclidean, and SNV methods (Fig. 3), as well as with second derivatives and Euclidean normalization (Fig. SM5) show that the overall behavior of the scores in the PC1 and PC2 planes is rather independent of the preprocessing procedure. As can be seen in Fig. SM6, a comparative PCA of spectra of samples S01 and S18 obtained in transmission (reference method for FTIR) with $\mathrm{ZnS}$ slides and reflection modes yield similar results.

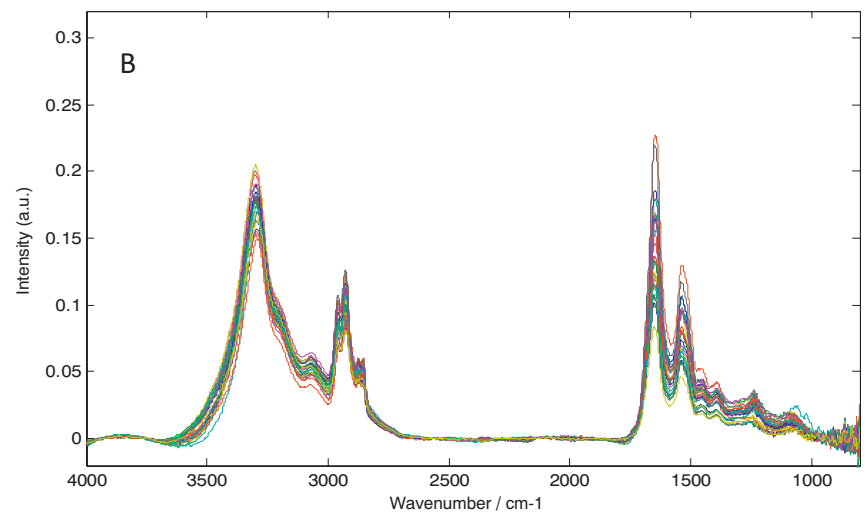

Fig. 2. IR spectra obtained for control HeLa cells after baseline correction. 

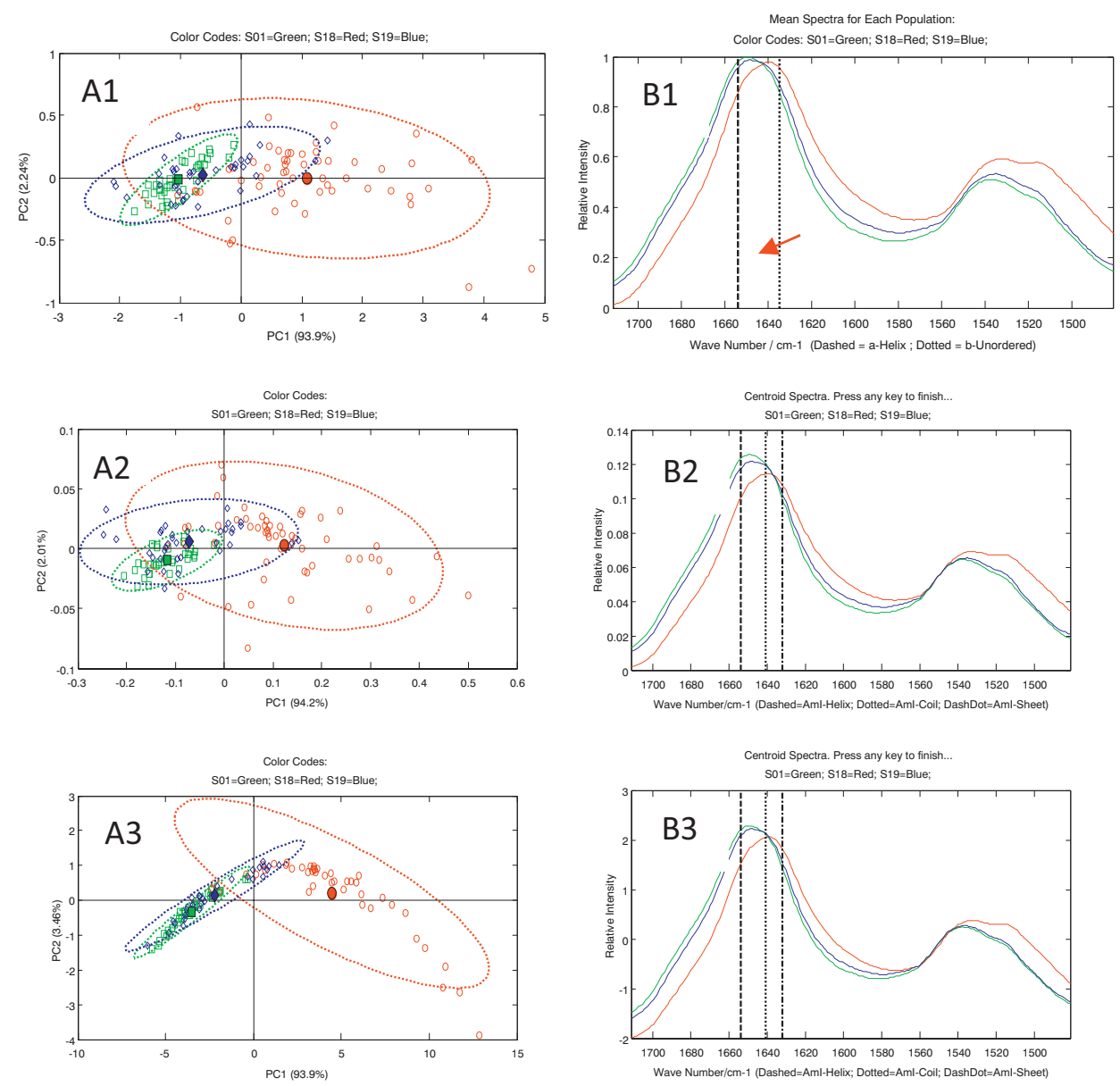

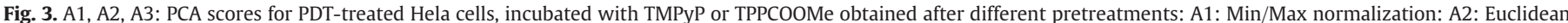

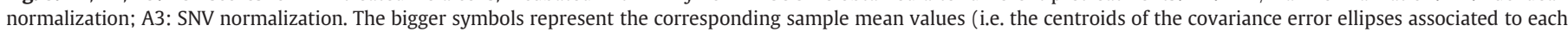

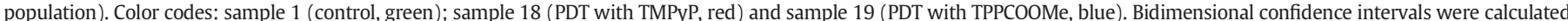

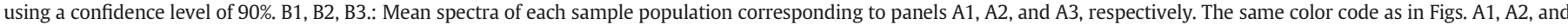
$\mathrm{A} 3$ is employed. (For interpretation of the references to color in this figure legend, the reader is referred to the web version of this article.)

Vertical lines in Fig. 3B1, B2, and B3 depict the wavenumbers expected for the peaks of $\alpha$-helix $\left(1654 \mathrm{~cm}^{-1}\right), \beta$-sheet $\left(1632 \mathrm{~cm}^{-1}\right)$, and unordered random coil $\left(1641 \mathrm{~cm}^{-1}\right)[26,27]$.

Fig. 3 shows a pronounced PDT effect in HeLa cells treated with TMPyP (sample 18). The beta sheet structure in the Amide I band (decrease of the portion of $\alpha$-helix), is affected by PDT, as indicated by the arrow in Fig. 3B1. This result is on line with the work published by S.Srichan [12], where it was found that PDT is also manifested by the appearance of beta sheets structure in the nucleus. We can also observe that there is an increase of the absorption in the region of shorter wavenumbers of the Amide II region. The low-wavenumber component of Amide II was previously assigned to tyrosine side chain contributions, to intramolecular $\beta$-structures, and to $\beta$-folded aggregates $[28,29]$. More recently, it was also suggested that the $\sim 1525 \mathrm{~cm}^{-1}$ component of Amide II band may be assigned to intramolecular $\beta$-sheets but also to the same type of protein folding described by the $1620 \mathrm{~cm}^{-1}$ frequency, and therefore to intermolecular $\beta$-aggregates [30]. Additionally, the PDT treatment in HeLa cells incubated with TMPyP results in a decrease of the Amide I/Amide II bands ratio, as already reported for cells exposed to thermal shock [30].

Fig. SM7 in the Supplementary Material compares the loadings vectors of samples S01, S18 and S19. The analysis shows that the vector associated with PC1 (solid line in Fig. SM7), which accounts for $>92 \%$ of the variance, helps to discriminate between the spectra of sample S18 and those of samples S01/S19. This vector presents the bands of Amide I and Amide II shifted at longer wavenumbers. On the other hand, the loading vectors of PC2, which accounts for $<4-5 \%$ of the variance, is associated to a difference in intensity of the spectra of samples S01 and S19, because the positions of the crests and troughs of the loading vectors for both samples are coincident.

The changes observed with visible light irradiation with TPРСООМеtreated cells (sample 19) is not induced by the increase of beta sheet structure (result not shown). In fact, the most significant difference is indicated by an enhancement in the dispersion of PCA scores, which correlates with an increase of the ellipse size (Fig. 3A1, A2, A3) and the number of spectra showing Mie scattering. The presence of a higher number of spectra with Mie scattering in PDT-treated samples compared to the control could be an evidence for late apoptosis/necrosis [27].

In order to investigate the effect of the PDT treatment on different biomolecules, additional wavenumber regions were chosen: proteinnucleic acids (1748-952 $\mathrm{cm}^{-1}$ ), proteins including the Amide III band (1748-1303 $\left.\mathrm{cm}^{-1}\right)$, and lipids $\left(2835-3000 \mathrm{~cm}^{-1}\right)$. After a detailed examination of these regions (see Fig. SM8 in the Supplementary Material) we conclude that the main observed differences are those already described within the Amide I and Amide II regions. Contrary to the results reported by Gasparri and Muzio [26], who observed that the ratio nucleic acids/Amide II decreases upon induction of apoptosis, we observe that the area of the nucleic acids signal increases more than that of Amide II (see Fig. SM8 in the Supplementary Material). This apparent discrepancy could be due to the different cell types and/or to the dissimilar experimental conditions employed, since the spectra measured by Gasparri and Muzio show a much higher relative contribution of the $900-1350 \mathrm{~cm}^{-1}$ region for their three cell types employed. 

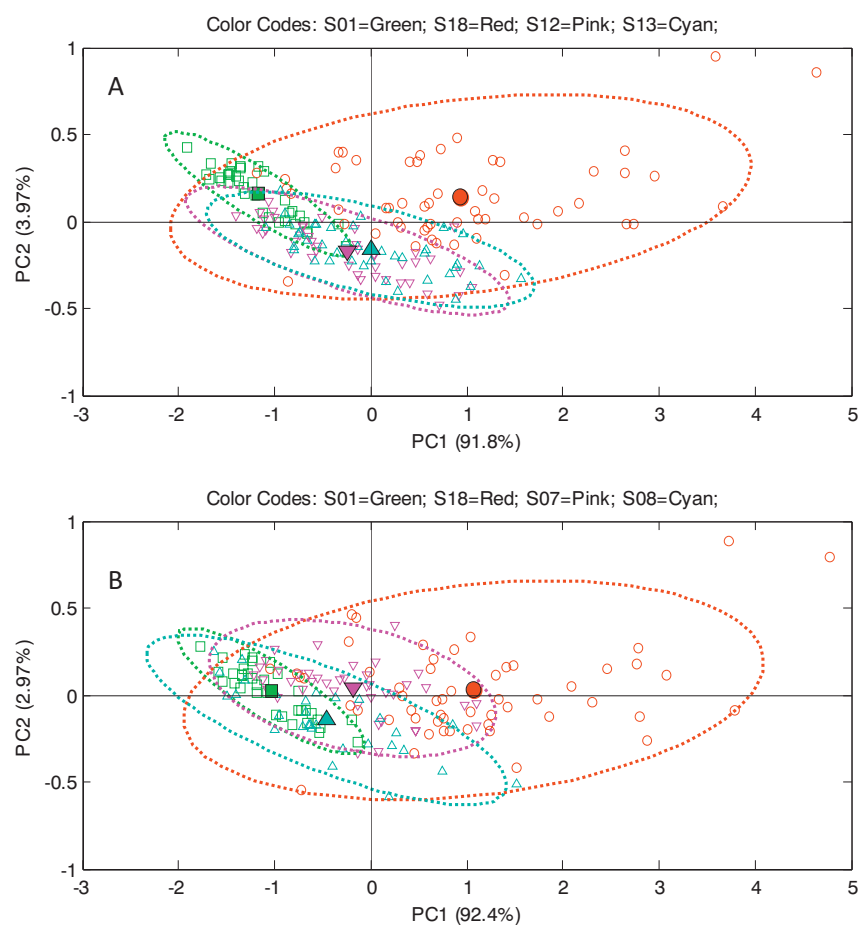

Fig. 4. A: PCA scores for PDT-treated Hela cells, incubated with TMPyP in the absence of quenchers (sample S18, red); in the presence of $5 \mu \mathrm{M}$ and $10 \mu \mathrm{M} \beta$-carotene (sample $\mathrm{S} 12$ in pink and S13 in cyan, respectively). The bigger symbols represent the corresponding sample means. B: PCA scores for PDT-treated Hela cells, incubated with TMPyP in the absence of quenchers (sample S18, red); in the presence of $30 \mu \mathrm{M}$ and 50 $\mu \mathrm{M}$ imidazole (sample S7 in pink and S8 in cyan, respectively). (For interpretation of the references to color in this figure legend, the reader is referred to the web version of this article.)

Additionally, we should consider that Gasparri and Muzio exposed their cells to an inductor of apoptosis. However, it has been well proven in the literature that PDT treatment leads to activation of two cell death pathways: apoptosis and/or necrosis [31]. This could be another reason for the difference in the nucleic acids/AmII ratio upon exposure to the inductor of apoptosis and to PDT.

\subsection{Quenchers Effects on PDT Treatment with HeLa Cells}

Comparison of data collected from PDT treated-HeLa cells (sample 18 ) with those also containing $\beta$-carotene, as a hydrophobic quencher, previously incorporated in these cells (sample 12 and sample 13) shows a photoprotective effect practically independent of the quencher concentration (see Fig. 4A for data treated with the Min/Max procedure), as can be concluded from the distance to the origin in the plots of PCA scores for both concentrations. Similar results are obtained with other pre-treatment procedures (see Fig. SM9 in the Supplementary Material). This observation is in line with recent reported MTT and bright field images results obtained after PDT treatment of HeLa cells incubated with this quencher. However, in that report there was a good dose effect correlation [7]. In that paper it was demonstrated that intracellular singlet oxygen, produced in a photosensitized process, is in fact not efficiently deactivated by $\beta$-carotene. That observation led to re-evaluation of the role of $\beta$-carotene as an antioxidant in mammalian systems and thus underscored the importance of mechanisms by which $\beta$-carotene inhibits radical reactions.

The other quencher studied here is imidazole as a model hydrophilic compound. As this molecule was not previously incorporated in HeLa cells, a key aspect of this study is to ensure that an appreciable amount of imidazole can be uptaken by the cells. Fluorescence images of HeLa cells containing the quencher support the incorporation (Fig. 5).

FTIR spectra of HeLa cells with TMPyP in the presence of imidazole also show a photoprotective effect, in this case dependent on the quencher concentration, as can be seen from comparison of the distance between the centroids for samples number 1 (control), 18 (PDT with TMPyP without quencher), 7 (PDT with TMPyP with $30 \mu \mathrm{M}$ imidazole), and 8 (PDT with TMPyP with $50 \mu \mathrm{M}$ imidazole) (Fig. 4B). This effect is also supported by the MTT assay (Fig. 6). No shift of the Amide I band was detected in samples containing $\beta$-carotene or imidazole with respect to the control experiments (see for instance Supplementary Material, Fig. SM9).

In the case of TPPCOOMe, PCA scores show a weaker effect compared to TMPyP (see above). Both quenchers lead to a photoprotective effect, especially at lower concentration. Compare samples S19, S15 and S16 for the effect of $\beta$-carotene and samples S19, S10, and S11 for imidazole (Fig. 7 for data pre-treated with the Min/Max normalization procedure). For similar results obtained with other pre-treatments see Fig. SM10 in the Supplementary Material. The photoprotective effect of $\beta$-carotene in HeLa cells using the same sensitizer was previously shown by MTT assays [7].

\subsection{Comparison of PDT Treatment on SKMEL-28, HaCat, and HeLa Cells}

For comparison FTIR experiments with SKMEL-28 and HaCat (human normal skin keratinocytes cells) were carried out.

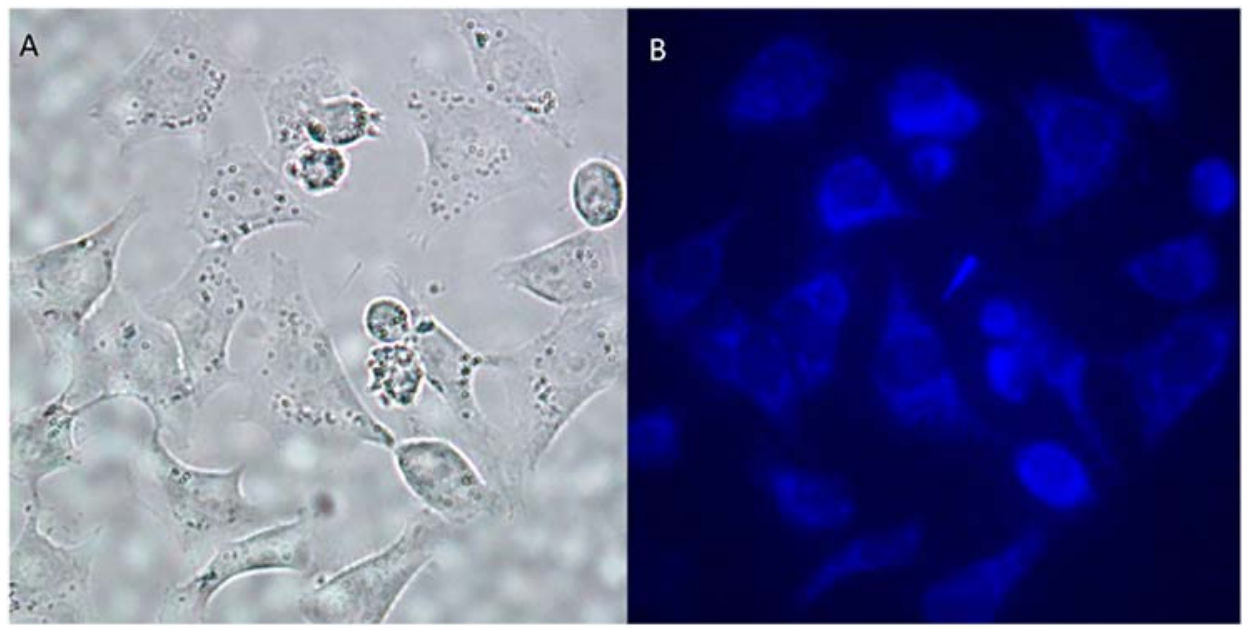

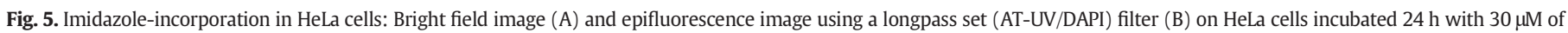
imidazole. Blank experiments with cells incubated without imidazole showed no fluorescence. 


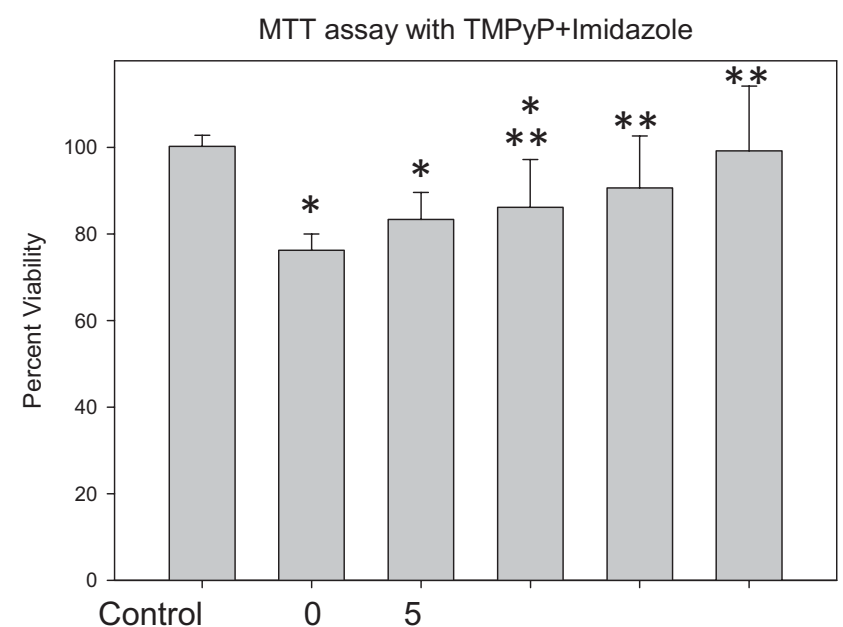

Fig. 6. Histograms showing the results of the MTT assay in PDT experiments with HeLa cells with TMPyP and different concentrations of imidazole as indicated. Values of formazan absorbance were normalized against average values obtained from cells to which a sensitizer and imidazole had not been added. Error bars refer to one standard deviation; in each case, the number of samples examined was at least 12 . The statistically significant difference between this particular number and the control (one asterisk), sample 18 (two asterisks) is indicated (one-way ANOVA with Tukey's posthoc test; $\mathrm{p}<.05$ ).

The effect of PDT with both sensitizers (TMPyP and TPPCOOMe) on SKMEL-28 and HaCat cells are shown in Fig. 8A and B, respectively, for data pre-treated with the Min/Max normalization procedure. Similar results are obtained with other pre-treatment procedures (see Fig. SM11 in the Supplementary Material). Larger differences in the PCA scores are observed for the tumoral SKMEL-28 treated cells than for the non-
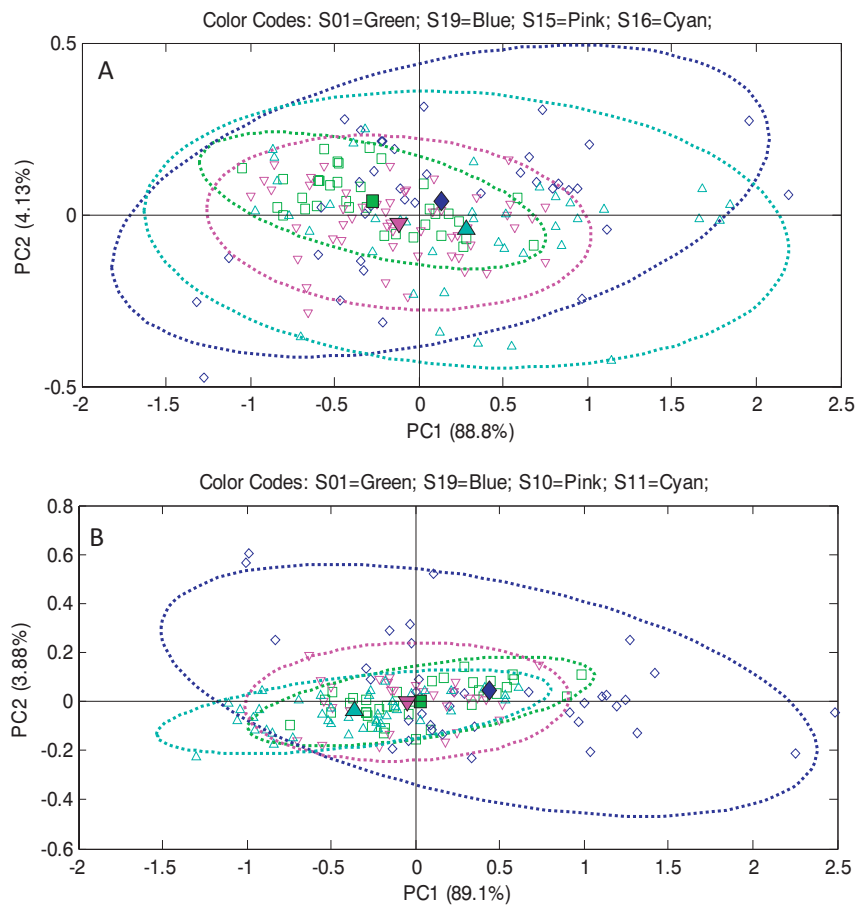

Fig. 7. A: PCA scores for PDT-treated HeLa cells, incubated with TPPCOOMe in the absence of quenchers (sample S19, blue); in the presence of $5 \mu \mathrm{M}$ (sample S15, pink) and $10 \mu \mathrm{M} \beta$ carotene (sample S16, cyan). The bigger symbols represent the corresponding sample means. B: PCA scores for PDT-treated Hela cells, incubated with TPPCOOMe in the absence of quenchers (sample S19, blue); in the presence of $30 \mu \mathrm{M}$ (sample S10, pink) and $50 \mu \mathrm{M}$ imidazole (S11, cyan). (For interpretation of the references to color in this figure legend, the reader is referred to the web version of this article.)
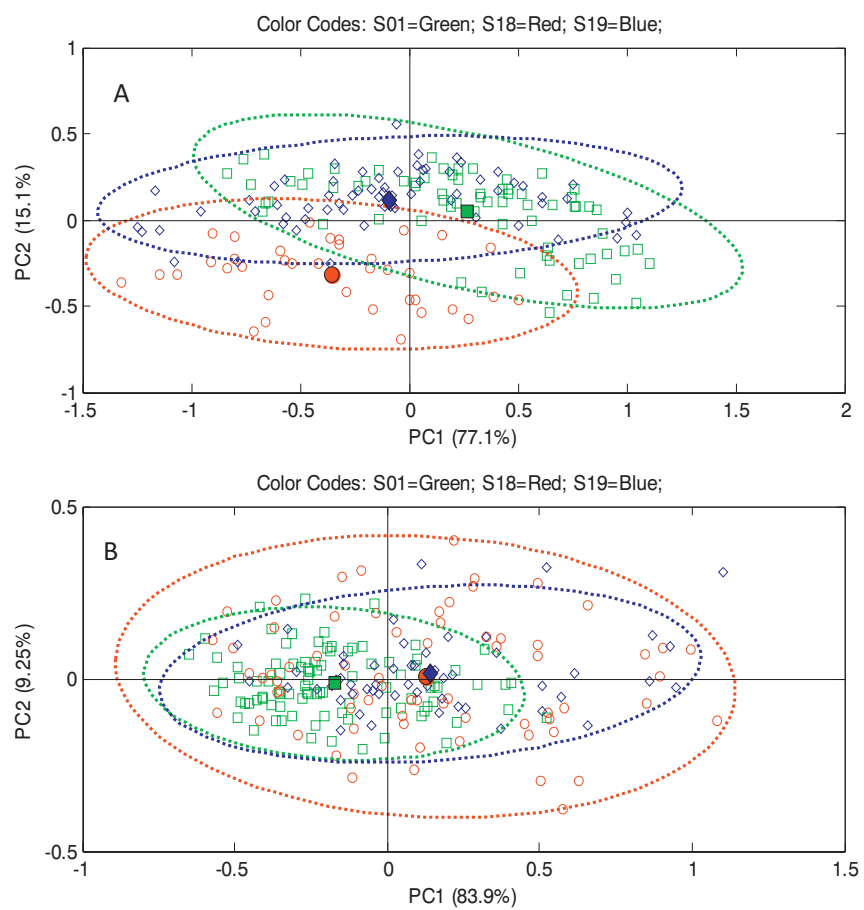

Fig. 8. PCA scores for PDT-treated SKMEL-28 cells (A) and HaCat cells (B), incubated with TMPyP or TPPCOOMe. The bigger symbols represent the corresponding sample means. Color codes: sample 1 (control, blue); sample 18 (PDT with TMPyP, red) and sample 19 (PDT with TPPCOOMe, red). (For interpretation of the references to color in this figure legend, the reader is referred to the web version of this article.)

malignant HaCat cells. For SKMEL-28 cells TMPyP is a more efficient PDT sensitizer than TPPCOOMe, whereas for HaCat cells there is no significant difference between mean values for both sensitizers. However, a higher dispersion of the data with HaCat cells is observed for TMPyP, which can be correlated with apoptosis (see above). This result indicates that TMPyP is a more efficient PDT sensitizer than TPPCOOMe.

On the other hand, the MTT assay seems to be less sensitive to cell type, as similar results are observed for SKMEL-28, HaCat, and HeLa cells (see Fig. 9). In all cases TMPyP seems to be a much better PDT photosensitizer than TPPCOOMe. The discrepancy between the results obtained with FTIR and MTT methods can be due to the different biological phenomena tested. The FTIR spectra in the frequency range evaluated here are sensitive to changes in secondary structure of proteins, whereas the MTT assay reflects the enzymatic mitochondrial activity.

FTIR spectra in the presence of $\beta$-carotene or imidazole with SKMEL28 and HaCat cells do not show any significant photoprotective effect. These results are in line with the MTT assays (see Fig. 10). For a better comparison of the three types of cells, the quenchers incubation conditions employed for SKMEL-28 and HaCat cells were the same as for HeLa cells. Thus, the lack of photoprotective effect could be due to lower effective quencher concentration inside the SKMEL-28 and HaCat cells compared to that in HeLa cells.

The FTIR and MTT results obtained with all cell lines tested show a higher PDT efficiency for TMPyP than for TPPCOOMe. In all cases the FTIR spectra in the region of the Amide I band show a more pronounced photodynamic effect in tumoral cell lines (HeLa and SKMEL-28). This is in line with the photoeffects of phthalocyanines modified with D-galactose, which were found to be higher on HeLa carcinoma cells than on non-malignat HaCaT cells [32]. Gomes et al. [13] studied the photodynamic effect of glycochlorin conjugates on human cancer epithelial cells and also found comparable results for HaCaT and HeLa cells, in agreement with our observations. However, the results seem to depend on several factors, such as the kind of assay, the photosensitizer employed, as well as the light source, and irradiation dose. For example, 


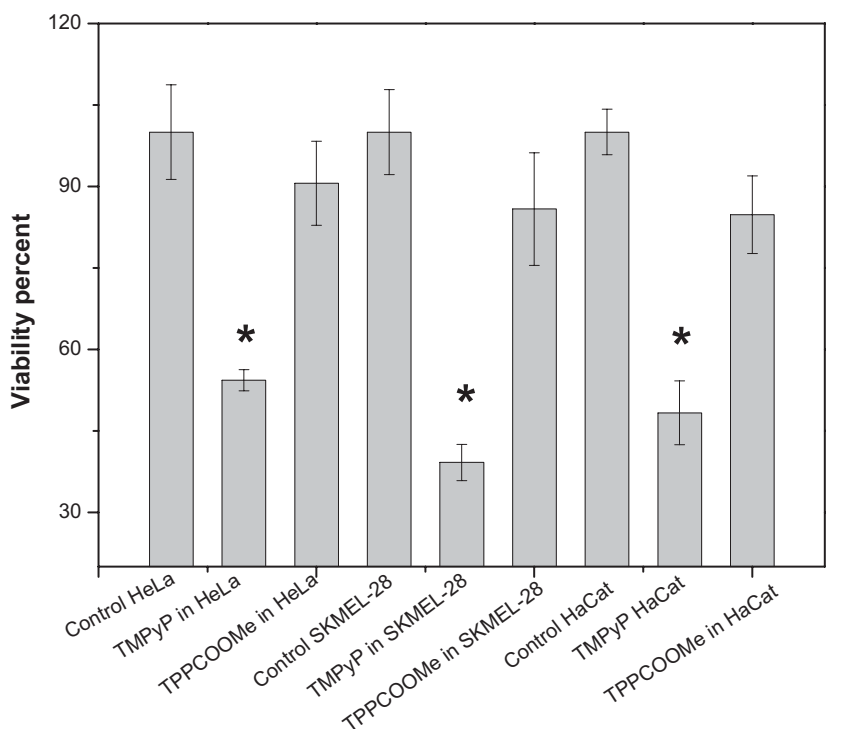

Fig. 9. Histograms showing the results of the MTT assay in PDT experiments with SKMEL28, HaCat, and HeLa cells as indicated. Values of formazan absorbance were normalized against average values obtained from the corresponding cells without sensitizer. Error bars refer to one standard deviation; in each case, the number of samples examined was at least 12 . The statistically significant difference between this particular number and the corresponding control (one asterisk) is indicated (one-way ANOVA with Tukey's posthoc test; $\mathrm{p}<.05$ ).

Acedo et al. [33] reported similar PDT effects of TMPyP on HeLa and Hacat cells.

\section{Conclusions}

An appropriate combination of FTIR microscopy and a solid statistical data analysis allowed us to obtain information of biochemical and biomedical relevance on early stages of apoptosis in PDT-treated tumoral and non-tumoral cells. The pre-treatment performed on the spectra enabled to focus on those samples exhibiting minimal scattering artifacts, which could mask the biological events of interest.

The PDT effects strongly depend on the sub-cellular localization of the photosensitizers and can be avoided by a proper use of different quenchers. In this regard, tumoral cells resulted more sensitive to PDT.

The most relevant effects were observed with PDT-treated HeLa cells employing TMPyP as sensitizer. The PDT treatment results in an increase of the absorption in the region of shorter wavenumbers of the Amide I and Amide II regions, which were assigned to intramolecular $\beta$-sheets and intermolecular $\beta$-aggregates [30]. Upon the PDT-treatment a decrease of the Amide I/Amide II bands ratio was also observed, in line with the response of cells exposed to thermal shock [30]. Additionally, the area of the nucleic acids signal was observed to increase comparatively more than that of Amide II.

Both compounds studied here, $\beta$-carotene and imidazole, show photoprotective effects in HeLa cells exposed to PDT either with TMPyP or TPCOOMe. The effect of the carotenoid was dose-independent, whereas a good correlation dose-response was found in the case of imidazole. The latter behavior could be relevant for the medical management of the induction of early apoptosis.

When SKMEL-28 or HaCat cells are employed non- significant photoprotective effects of $\beta$-carotene and imidazole are observed, probably due to lower effective intracellular quencher concentration compared to that in HeLa cells.

\section{Acknowledgements}

We acknowledge SOLEIL for provision of synchrotron radiation facilities and we would like to thank William Andre, Christophe Sandt,
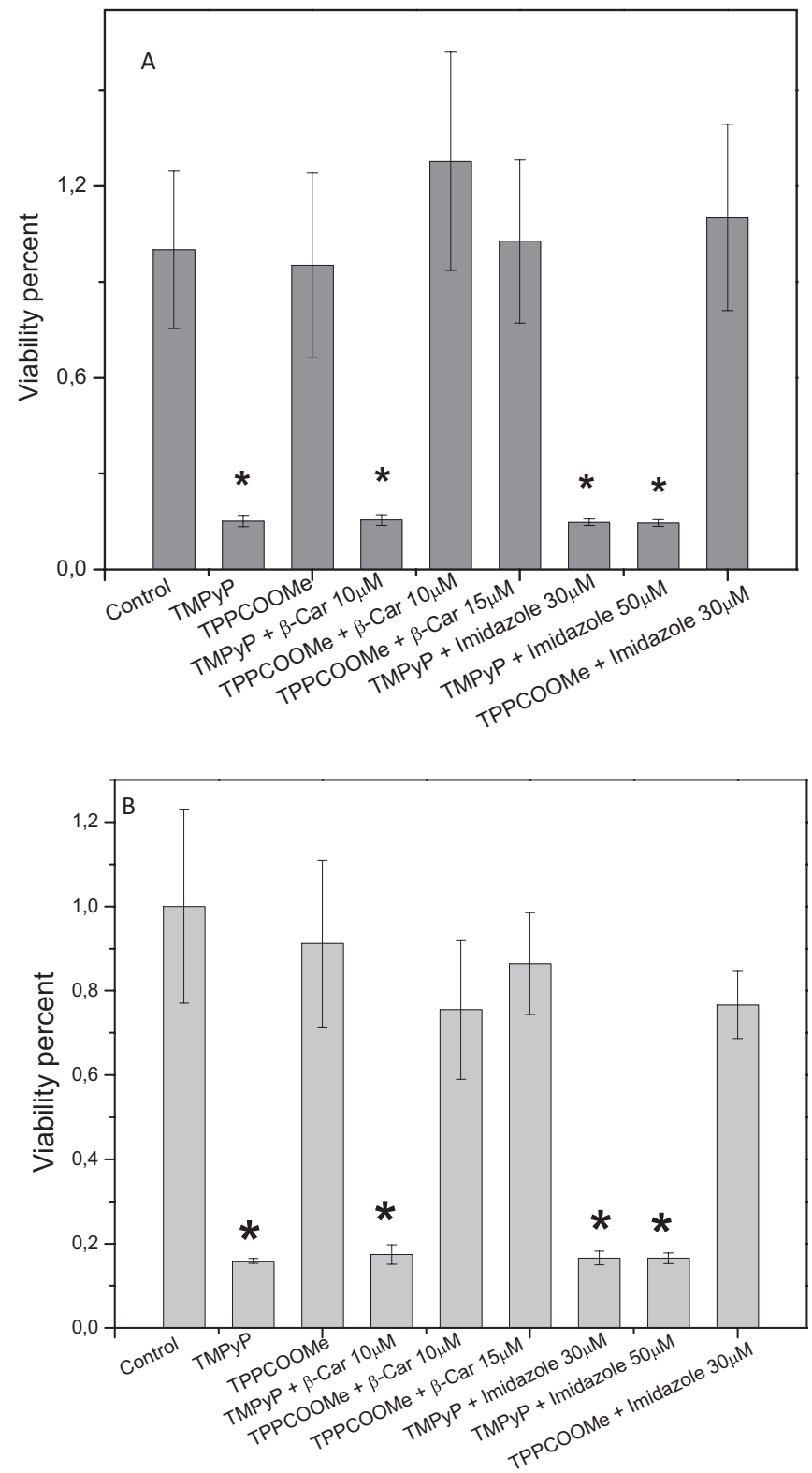

Fig. 10. Histograms showing the results of the MTT assay in PDT experiments with SKMEL28 (A) and HaCat (B) cells with TMPyP or TPPCOOMe and different concentrations of imidazole or $\beta$-carotene as indicated. Values of formazan absorbance were normalized against average values obtained from the corresponding cells without sensitizer. Error bars refer to one standard deviation; in each case, the number of samples examined was at least 12 . The statistically significant difference between this particular number and the corresponding control (one asterisk) is indicated (one-way ANOVA with Tukey's posthoc test; $\mathrm{p}<.05$ ).

Ferenc Borondics, and Paul Dumas for assistance in using "SMIS" beamline and Daniel Castrogiovanni for assistance with the cells cultures. G.N.B. and F.S.G.E. are research members from CONICET (Argentina) D.O.M. is a research member from CIC (Province of Buenos Aries, Argentina) and J. P. is a technical professional member from CIC (Province of Buenos Aries, Argentina).

This work was partially supported by grant PICT 2012-1817 from ANPCyT, Argentina.

\section{Funding}

This research was partially supported by grants number 20130276 and 20141062 from SOLEIL and a bilateral cooperation agreement MinCyT (Argentina)/SOLEIL. 


\section{Notes}

The authors declare no competing financial interest.

\section{Appendix A. Supplementary Data}

Supplementary data to this article can be found online at https://doi. org/10.1016/j.saa.2018.01.027.

\section{References}

[1] C. Schweitzer, R. Schmidt, Physical mechanisms of generation and deactivation of singlet oxygen, Chem. Rev. 103 (2003) 1685-1757, https://doi.org/10.1021/ cr010371d.

[2] M.J. Paterson, O. Christiansen, F. Jensen, P.R. Ogilby, Overview of theoretical and computational methods applied to the oxygen-organic molecule photosystem, Photochem. Photobiol. 82 (2006) 1136, https://doi.org/10.1562/2006-03-17-IR-851.

[3] C.S. Foote, E.L. Clennan, Properties and reactions of singlet dioxygen, Act. Oxyg. Chem. Springer Netherlands, Dordrecht 1995, pp. 105-140, https://doi.org/10. 1007/978-94-007-0874-7_4.

[4] K.R. Weishaupt, C.J. Gomer, T.J. Dougherty, Identification of singlet oxygen as the cytotoxic agent in photoinactivation of a murine tumor, Cancer Res. 36 (1976) 2326-2329http://www.ncbi.nlm.nih.gov/pubmed/1277137, Accessed date: 9 August 2016.

[5] R.W. Redmond, I.E. Kochevar, Spatially resolved cellular responses to singlet oxygen, Photochem. Photobiol. 82 (2006) 1178-1186, https://doi.org/10.1562/2006-04-141R-874.

[6] Raymond Bonnett, Chemical aspects of photodynamic therapy, Gordon \& Breach, London, 2000https://books.google.com.ar/books?id=yDF_PInZNGwC\&source= gbs_navlinks_s.

[7] G.N. Bosio, T. Breitenbach, J. Parisi, M. Reigosa, F.H. Blaikie, B.W. Pedersen, E.F.F. Silva, D.O. Mártire, P.R. Ogilby, Antioxidant $\beta$-carotene does not quench singlet oxygen in mammalian cells, J. Am. Chem. Soc. 135 (2013)https://doi.org/10.1021/ja308930a.

[8] L.O. Klotz, C. Pellieux, K. Briviba, C. Pierlot, J.M. Aubry, H. Sies, Mitogen-activated protein kinase (p38-, JNK-, ERK-) activation pattern induced by extracellular and intracellular singlet oxygen and UVA, Eur. J. Biochem. 260 (1999) 917-922http://www. ncbi.nlm.nih.gov/pubmed/10103024, Accessed date: 27 December 2017.

[9] B. Bellei, A. Pitisci, E. Izzo, M. Picardo, G. Costin, V. Hearing, Y. Miyamura, S. Coelho, R Wolber, S. Miller, K. Wakamatsu, A. Winder, T. Kobayashi, K. Tsukamoto, K. Urabe, P. Aroca, E. Land, C. Ramsden, P. Riley, V. Hearing, K. Tsukamoto, A. Slominski, D. Tobin, S. Shibahara, J. Wortsman, A. Slominski, K. Yasumoto, K. Yokohama, K. Takahashi, Y. Tomita, S. Shibahara, C. Bertolotto, K. Bille, J. Ortonne, R. Ballotti, C. Bertolotto, R. Buscà, P. Abbe, K. Bille, E. Aberdam, A. Hachiya, A. Kobayashi, Y. Yoshida, T. Kitahara, Y. Takema, A. Slominski, D. Tobin, S. Shibahara, J. Wortsman, J. Wu, J. Saint-Jeannet, P. Klein, M. Ikeya, S. Lee, J. Johnson, A. McMahon, S. Takada, B. Bellei, A. Pitisci, C. Catricalà, L. Larue, M. Picardo, A. Schepsky, K. Bruser, G. Gunnarsson, J. Goodall, J. Hallsson, M. Peifer, P. Polakis, J. Behrens, J. von Kries, M. Kühl, L. Bruhn, D. Wdlich, T. Jin, I.G. Fantus, J. Sun, M. Shitashige, S. Hirohashi, T. Yamada, A. Kikuchi, S. Kishida, H. Yamamoto, R. Daugherty, C. Gottardi, S. Hino, C. Tanji, K. Nakayama, A. KIkuchi, W. van Veelen, N. Le, W. Helvensteinijn, L. Blonden, M. Theeuwes, O. Eichhoff, A. Weeraratna, M. Zipser, L. Denat, D. Widmer, M. Lepourcelet, Y. Chen, D. France, H. Wang, P. Crews, M. McMillan, M. Kahn, M Eguchi, C. Nguyen, S. Lee, M. Kahn, H. Ma, C. Naguyen, K. Lee, M. Kahn, C. Thorne, A. Hanson, J. Schneider, E. Tahinci, D. Orton, T. Biechele, N. Camp, D. Fass, R. Kulikauskas, N. Robin, H. Widlund, M. Horstmann, E. Prince, J. Cui, S. Lessnick, Y. Yamaguchi, S. Itami, H. Watabe, K. Yasumoto, Z. Abdel-Malek, Y. Yamaguchi, T. Passeron, H. Watabe, K. Yasumoto, F. Rouzaud, D. Kim, S. Park, S. Kwon, J. Na, C. Huh, S. Singh, C. Sarkar, S. Mallick, B. Saha, R. Bera, K. Birkenkamp, L. Tuyt, C. Lummen, A. Wierenga, W. Kruijer, M. Huang, Y. Wang, M. Collins, J. Gu, B. Mitchell, M. Shibazaki, T. Takeuchi, S. Ahmed, H. Kikuchi, N. Shanware, L. Williams, M. Bowler, R. Tibbetts, M. Menon, A. Kotlyarov, M. Gaestel, B. Bellei, V. Maresca, E. Flori, A. Pitisci, L. Larue, E. Medrano, F. Yang, R. Boissy, J. Farooqui, V. Shah, G. Gonzales, M. Montminy, J. Chrivia, R. Kwok, N. Lamb, M. Hagiwara, R. Montminy, R. Goodman, H. Saito, K. Yasumoto, K. Takeda, K. Takahashi, A. Fukuzaki, A. Watanabe, K. Takeda, B. Ploplis, M. Tachibana, N. Bondurand, V. Pingault, D. Goerich, N. Lemort, E. Sock, K. Takeda, K. Yasumoto, R. Takada, S. Takada, K. Watanabe, R. Bikkavilli, M. Feigin, C. Malbon, I. Červenka, J. Wolf, J. Mašek, P. Krejci, W. Wilcox, F. Verkaar, A. van der Doelen, J. Snmits, W. Blakesteijn, G. Zaman, A. Ho, L. Prince, M. Mackova, C. Chik, J. Bain, L. Plater, M. Elliott, N. Shpiro, J. Hastie, B. Bellei, E. Flori, E. Izzo, V. Maresca, M. Picardo, F. Takahashi-Yanaga, M. Kahn, J. Teo, M. Kahn, M. Shibazaki, T. Takeuchi, S. Ahmed, H. Kikuchi, L. Dickinson, R. Gulizia, J. Trauger, E. Baird, D. Mosier, L. Supekova, J. Pezacki, A. Su, C. Loweth, R. Riedl, L. Garraway, H. Widlund, M. Rubin, G. Getz, A. Berger, Inhibition of melanogenesis by the pyridinyl imidazole class of compounds: possible involvement of the Wnt/ $\beta$-catenin signaling pathway, PLoS One 7 (2012), e33021. https://doi.org/10.1371/journal.pone.0033021.

[10] L.M. Miller, P. Dumas, From structure to cellular mechanism with infrared microspectroscopy, Curr. Opin. Struct. Biol. 20 (2010) 649-656, https://doi.org/10. 1016/j.sbi.2010.07.007.

[11] P. Dumas, G.D. Sockalingum, J. Sulé-Suso, Adding synchrotron radiation to infrared microspectroscopy: what's new in biomedical applications? Trends Biotechnol. 25 (2007) 40-44, https://doi.org/10.1016/j.tibtech.2006.11.002.
[12] S. Chio-Srichan, M. Réfrégiers, F. Jamme, S. Kascakova, V. Rouam, P. Dumas, Photosensitizer effects on cancerous cells: a combined study using synchrotron infrared and fluorescence microscopies, Biochim. Biophys. Acta, Gen. Subj. 1780 (2008) 854-860, https://doi.org/10.1016/j.bbagen.2008.02.004.

[13] A.T.P.C. Gomes, M.A.F. Faustino, M.G.P.M.S. Neves, V.F. Ferreira, A. Juarranz, J.A.S Cavaleiro, F. Sanz-Rodríguez, A. Master, M. Livingston, A.S. Gupta, P. SkupinMrugalska, J. Piskorz, T. Goslinski, J. Mielcarek, K. Konopka, N. Düzgüneş, X. Zheng R.K. Pandey, J.D. Miller, E.D. Baron, H. Scull, A. Hsia, J.C. Berlin, T. McCormick, V. Colussi, M.E. Kenney, K.D. Cooper, N.L. Oleinick, R.R. Allison, C.H. Sibata, R.R. Allison, K. Moghissi, A.A. Aksenova, Y.L. Sebyakin, A.F. Mironov, R.J. Hilf, J.A.S Cavaleiro, J.P.C. Tome, M.A.F. Faustino, S. Silva, M.R. Pereira, P. Silva, F.A.A. Paz, M. A.F. Faustino, J.A.S. Cavaleiro, J.P.C. Tomé, A.T.P.C. Gomes, R.A.C. Leão, F.C. Silva, M. G.P.M.S. Neves, M.A.F. Faustino, A.C. Tomé, A.M.S. Silva, S. Pinheiro, M.C.B.V. Souza, V.F. Ferreira, J.A.S. Cavaleiro, A.S.L. Derycke, P.A.M. Witte, F. Ginevra, S. Biffanti, A Pagnan, R. Biolo, E. Reddi, G. Jori, J.L. Merlin, S. Azzi, D. Lignon, C. Ramacci, N. Zeghari, F. Guillemin, T. Mosmann, A. Juarranz, J. Espada, J.C. Stockert, A. Villanueva, S. Polo, V. Dominguez, M. Cañete, M.C. DeRosa, R.J. Crutchley, K. Oda, S. Ogura, I. Osekura, P. Boukamp, R.T. Petrussevska, D. Breitkreutz, J. Hornung, A. Markham, N.E. Fusenig, L.B. Josefsen, R.W. Boyle, V.V. Serra, A. Zamarrón, M.A.F. Faustino, M.C.I. Cruz, A. Blázquez, J.M.M. Rodrigues, M.G.P.M.S. Neves, J.A.S. Cavaleiro, A. Juarranz, F. Sanz-Rodríguez, I. Yoon, J.Z. Li, Y.K. Shim, M. Hollstein, D. Sidransky, B. Vogelstein, C.C. Harris, A.R.M. Soares, M.G.P.M.S. Neves, A.C. Tomé, M. C.I. la Cruz, A. Zamarron, E. Carrasco, S. González, J.A.S. Cavaleiro, T. Torres, D.M. Guldi, A. Juarranz, G. Zheng, A. Graham, M. Shibata, J.R. Missert, A.R. Oseroff, T.J. Dougherty, R.K. Pandey, S. Vedachalam, B.H. Choi, K.K. Pasunooti, K.M. Ching, K. Lee, H.S. Yoon, X.W. Liu, J.M. Rini, T.A.F. Cardote, J.F.B. Barata, M.A.F. Faustino, A Preuss, M.G.P.M.S. Neves, J.A.S. Cavaleiro, C.I.V. Ramos, M.G.O. Santana-Marques, B. Röder, R.B. Hamanaka, N.S. Chandel, C.S. Jin, G. Zheng, Photodynamic effect of glycochlorin conjugates in human cancer epithelial cells, RSC Adv. 5 (2015) 33496-33502, https://doi.org/10.1039/C5RA04345J.

[14] M.D. Kars, R. Kara, Y. Gündoğdu, A. Kepceoğlu, H.Ş. Kılıç, Femtosecond laser induced photodynamic therapy on 5-ALA treated SKMEL-30 cells: an efficient theranostic strategy to combat melanoma, Biomed Pharmacother 68 (2014) 657-662, https:// doi.org/10.1016/j.biopha.2014.04.001

[15] Y. Quan, S.O. Pehkonen, M.B. Ray, Evaluation of three different lamp emission models using novel application of potassium ferrioxalate actinometry, Ind. Eng. Chem. Res. 43 (2004) 948-955, https://doi.org/10.1021/ie0304210.

[16] E. Gazi, J. Dwyer, N.P. Lockyer, J. Miyan, P. Gardner, C. Hart, M. Brown, N.W. Clarke, Fixation protocols for subcellular imaging by synchrotron-based Fourier transform infrared microspectroscopy, Biopolymers 77 (2005) 18-30, https://doi.org/10. 1002/bip.20167.

[17] S. Hatz, J.D.C. Lambert, P.R. Ogilby, Measuring the lifetime of singlet oxygen in a single cell: addressing the issue of cell viability, Photochem. Photobiol. Sci. 6 (2007) 1106-1116, https://doi.org/10.1039/b707313e.

[18] G. Nikkhah, J.C. Tonn, O. Hoffmann, H.P. Kraemer, J.L. Darling, W. Schachenmayr, R. Schönmayr, The MTT assay for chemosensitivity testing of human tumors of the central nervous system. Part II: evaluation of patient- and drug-specific variables, J. Neuro-Oncol. 13 (1992) 13-24http://www.ncbi.nlm.nih.gov/pubmed/1613536, Accessed date: 9 August 2016.

[19] Y. Liu, D.A. Peterson, H. Kimura, D. Schubert, Mechanism of cellular 3-(4,5-dimethylthiazol-2-yl)-2,5-diphenyltetrazolium bromide (MTT) reduction, J. Neurochem. 69 (1997) 581-593http://www.ncbi.nlm.nih.gov/pubmed/9231715, Accessed date: 9 August 2016.

[20] P.R. Twentyman, M. Luscombe, A study of some variables in a tetrazolium dye (MTT) based assay for cell growth and chemosensitivity, Br. J. Cancer 56 (1987) 279-285http://www.ncbi.nlm.nih.gov/pubmed/3663476, Accessed date: 9 August 2016.

[21] P. Lasch, Spectral pre-processing for biomedical vibrational spectroscopy and microspectroscopic imaging, Chemom. Intell. Lab. Syst. 117 (2012) 100-114, https://doi.org/10.1016/j.chemolab.2012.03.011.

[22] A. Kohler, J. Sulé-Suso, G.D. Sockalingum, M. Tobin, F. Bahrami, Y. Yang, J. Pijanka, P. Dumas, M. Cotte, D.G. van Pittius, G. Parkes, H. Martens, Estimating and correcting mie scattering in synchrotron-based microscopic fourier transform infrared spectra by extended multiplicative signal correction, Appl. Spectrosc. 62 (2008) 259-266, https://doi.org/10.1366/000370208783759669.

[23] Å. Smund Rinnan, F. Van Den Berg, S.B. Engelsen, Review of the Most Common Preprocessing Techniques for Near-infrared Spectra, (n.d.). doi:https://doi.org/10.1016/ j.trac.2009.07.007.

[24] J. Filik, M.D. Frogley, J.K. Pijanka, K. Wehbe, G. Cinque, Electric field standing wave artefacts in FTIR micro-spectroscopy of biological materials, Analyst 137 (2012) 853, https://doi.org/10.1039/c2an15995c.

[25] P. Bassan, H.J. Byrne, F. Bonnier, J. Lee, P. Gardner, Resonant Mie Scattering in Infrared Spectroscopy of Biological Materials - Understanding the "Dispersion Artefact", 2009, 2009 1586-1593, https://doi.org/10.1039/b904808a.

[26] F. Gasparri, M. Muzio, Monitoring of apoptosis of HL60 cells by Fourier-transform infrared spectroscopy, Biochem. J. 369 (2003) 239-248, https://doi.org/10.1042/ BJ20021021.

[27] W. André, C. Sandt, P. Dumas, P. Djian, G. Hoffner, Structure of inclusions of Huntington's disease brain revealed by synchrotron infrared microspectroscopy: polymorphism and relevance to cytotoxicity, Anal. Chem. 85 (2013) 3765-3773, https://doi.org/10.1021/ac400038b.

[28] A. Barth, The infrared absorption of amino acid side chains, Prog. Biophys. Mol. Biol. 74 (2000) 141-173http://www.ncbi.nlm.nih.gov/pubmed/11226511, Accessed date: 27 December 2017.

[29] E. Giorgini, C. Conti, P. Ferraris, S. Sabbatini, G. Tosi, C. Rubini, L. Vaccari, G. Gioacchini, O. Carnevali, Effects of Lactobacillus rhamnosus on zebrafish oocyte 
maturation: an FTIR imaging and biochemical analysis, Anal. Bioanal. Chem. 398 (2010) 3063-3072, https://doi.org/10.1007/s00216-010-4234-2.

[30] E. Mitri, S. Kenig, G. Coceano, D.E. Bedolla, M. Tormen, G. Grenci, L. Vaccari, Time-resolved FT-IR microspectroscopy of protein aggregation induced by heat-shock in live cells, Anal. Chem. 87 (2015) 3670-3677, https://doi.org/10.1021/ac5040659.

[31] M. Kubiak, L. Łysenko, H. Gerber, R. Nowak, Cell reactions and immune responses to photodynamic therapy in oncology Procesy komórkowe oraz odpowiedz immunologiczne na terapię fotodynamiczną w onkologii, Postepy Hig. Med. Dosw. 70 (2016) 735-742http://www.phmd.pl/fulltxt.php?ICID=1208196, Accessed date: 27 December 2017.

[32] A.R.M. Soares, M.G.P.M.S. Neves, A.C. Tomé, M.C. Iglesias-de la Cruz, A. Zamarrón, E. Carrasco, S. González, J.A.S. Cavaleiro, T. Torres, D.M. Guldi, A. Juarranz,
Glycophthalocyanines as photosensitizers for triggering mitotic catastrophe and apoptosis in cancer cells, Chem. Res. Toxicol. 25 (2012) 940-951, https://doi.org/10. 1021/tx300035a.

[33] P. Acedo, J.C. Stockert, M. Cañete, A. Villanueva, Two combined photosensitizers: a goal for more effective photodynamic therapy of cancer, Cell Death Dis. 5 (2014), e1122.

[34] P.E. Hartman, Z. Hartman, K.T. Ault, Scavenging of singlet molecular oxygen by imidazole compounds: high and sustained activities of carboxy terminal histidine dipeptides and exceptional activity of imidazole-4-acetic acid, Photochem. Photobiol. 51 (1) (1990) 59-66. 